\title{
METHODS OF DETERMINATION OF SUM OF FLAVONOIDS IN HERBAL PRODUCTS BY SPECTROPHOTOMETRIC METHODS
}

\author{
Hudz Nataliia ${ }^{1}$, Nikolaieva Nataliia ${ }^{3}$, Konyk Chrystyna ${ }^{1}$, \\ Kaplun Ivanna', Šimková Jana ${ }^{2}$, Grygorieva Olga ${ }^{4}$
}

\author{
'Department of Drug Technology and Biopharmaceutics, Danylo Halytsky Lviv National \\ Medical University, Ukraine \\ ${ }^{2}$ Department of Genetics and Plant Breeding, Slovak University of Agriculture in Nitra, Slovak Republic \\ ${ }^{3}$ Institute of Biodiversity Conservation and Biosafety, Slovak University of Agriculture in Nitra, Slovak Republic \\ ${ }^{4}$ M.M. Gryshko National Botanical Garden of Ukraine of National Academy of Sciences, Kyiv, Ukraine
}

\section{СПОСОБИ ВИЗНАЧЕННЯ СУМАРНОГО ВМІСТУ ФЛАВОНОЇДІВ В РОСЛИННИХ ПРОДУКТАХ СПЕКТРОФОТОМЕТРИЧНИМ МЕТОДОМ}

\author{
Гудзь Наталія, Ніколаєва Наталія, Коник Христина, \\ Каплун Іванна, Шимкова Яна, Григор'єва Ольга
}

Flavonoidcontaining plants attract the attention of researchers due to their prospect in obtaining food products and medicines with various pharmacological effects (anti-inflammatory, vessel protective, choleretic, hepatoprotective, radioprotective, antitumor, immunomodulatory, antimicrobial effects, etc.). For determining the total content of flavonoids, the method of differential spectrophotometry with a reagent of aluminum chloride is the most often used based on the complex formation of aluminum with the C-4 keto group and the hydroxyl groups of C-3 and C-5, as well as other hydroxyl groups of the flavonoid rings $A$ and/or $B$. As compensation solution is used a mixture which contains the same components as the test solution, with the exception of aluminum chloride, the volume of which is replaced by the solvent on which aluminum chloride was prepared. Such a modification makes it possible to exclude the influence of colored compounds on the results of the analysis. On the basis of literary data and own research, practical approaches for methods of determining the total content of flavonoids and the identification of the dominant group of flavonoids are given. The optical density of the reaction mixture of an extract with $1 \mathrm{ml}$ of a $2 \%$ solution of aluminum chloride hexahydrate should be in the range from 0,1 to 1,0 using $1 \mathrm{ml}$ of the extract or its appropriate dilution. For each plant, it is necessary to set the time of stability of flavonoids with aluminum chloride. In the process of own research, this complex was stable for 65-95 minutes. The study of the total content of flavonoids should be carried out with the identification of the dominant group of flavonoids by determining the maximum absorption in the differential spectrum of the extract with $1 \mathrm{ml}$ of a $2 \%$ solution of aluminum chloride. The maximum absorption is also required to select an analytical marker with an identical maximum of absorption of its complex with aluminum chloride in an identical solvent. Spectrometric studies should be supplemented by chromatography to confirm the correct choice of analytical marker.

Keywords: flavonoids; spectrophotometry; rutine; quercetin; Corylus avellana L.; bee bread

*Corresponding author: Nataliia Hudz, Department of Drug Technology and Biopharmaceutics, Danylo Halytsky Lviv National Medical University, Ukraine, $₫$ natali_gudz@ukr.net 


\section{Вступ}

Відомо, що в арсеналі лікарських засобів, які застосовують у традиційний та західній медицині, значну частину складають засоби рослинного походження. Значні ресурси, доступність сировини, можливість культивування роблять рослинну сировину перспективним об'єктом дослідження з метою розробки нових лікарських засобів та харчових продуктів рослинного походження (Шостак, 2014а, Шостак, 20146). Флавоноїдовмісні рослини привертають увагу дослідників внаслідок їх перспективності в отриманні харчових продуктів та лікарських препаратів різної фармакологічної дії. Флавоноїди - фенольні сполуки, які представляють різні похідні фенілхроману або фенілхромону, знайдені майже у всіх частинах вищих рослин у вигляді глікозидів і /або агліконів. Якісний склад і кількісний вміст флавоноїдів залежить від роду та виду рослини (Санникова, 2016). Метою даної роботи $\epsilon$ узагальнення літературних даних щодо стандартизації рослинної сировини за кількісним вмістом флавоноїдів, у тому числі щодо вибору аналітичного маркеру, довжини хвилі, за якої проводяться вимірювання, та наведення підходів щодо розробки методики кількісного визначення флавоноїдів методом диференціальної спектрофотометрії з реактивом алюмінію хлоридом на основі літературних даних та власних досліджень.

\section{Матеріали та методи}

У роботі використовувалися методи літературного пошуку, узагальнення та систематизація літературних даних та власних досліджень, спектрофотометричний метод. Як об'єкти дослідження були використані ліщи́на звича́йна (Corylus avellana L.), перга, софора японська (Styphnolobium japonicum L.), лушпиння цибулі, цмин піщаний (Helichrysum arenarium (L.) Moench), прополіс, плоди шипшини собачої (Rosa canina L.); аналітичні маркери - кверцетину дигідрат, рутину тригідрат, хризин, апігенін, лютеолін, мірецин. У власних дослідженнях використовувалися ліщи́на звичайна, перга, та аналітичні маркери кверцетину дигідрат, рутину тригідрат.

\section{Результати та їх обговорення}

Флавоноїди проявляють протизапальну, капілярозміцнюючу, жовчогінну, гепатопротекторну, радіопротекторну, протипухлинну, імуномодулюючу, протимікробну дію тощо. За останнє десятиріччя особливий інтерес викликає антиоксидантна дія флавоноїдів, їх здатність зв'язувати вільні радикали, які $\epsilon$ причиною виникнення у людини багатьох важких патологій. За антиоксидантною дією флавоноїди перевершують вітаміни С та Е і каротиноїди. Флавоноїди гальмують дію вільних радикалів безпосередньо за рахунок усунення радикалів шляхом донації атома гідрогену гідроксильної групи і утворення стабільного флавоноїдного феноксильного радикалу та стабільної молекули-акцептора гідрогену (Ломбоева, 2008; Чечета, 2011; Сорокина, 2013; Ivanišová et al., 2015; Литвиненко, 2016; Fatrcová-Šramková, 2016). Tому стандартизація рослинної сировини та продуктів бджільництва (перга, прополіс) за вмістом флавоноїдів $\epsilon$ доволі актуальною тематикою.

У рослинних об'єктах флавоноїди в основному містяться у вигляді сумішей різних глікозидів, які належать до різних груп флавоноїдів, що ускладнює вибір специфічного легкодоступного методу їх кількісного визначення і вимагає проведення системних досліджень. На початкових етапах розробки рослинних продуктів важливим питанням $\epsilon$ розробка методики швидкого визначення сумарного вмісту флавоноїдів, яка дає можливість при подальших дослідженнях оптимізувати технологію рослинного продукту (вибір розчинника та його оптимальної концентрації, методики екстракції, співвідношення «сировина-екстрагент», температурного режиму та часу екстракції, а також ступеня подрібнення сировини тощо) з метою максимальної екстракції біологічно активних сполук (Ломбоева, 2008; Чечета, 2011). Так, при екстрагуванні бруньок та листя берези бородавчастої використано спирт етиловий 
у концентраціях 60, 65, 70 \% та обрано такі методи екстрагування, як перколяцію і прискорену дробну мацерацію.

Спиртові розчини такої концентрації максимально екстрагують основні діючі речовини флавоноїди (як у формі агліконів, так і у формі глікозидів) та ефірну олію. Зниження концентрації спирту призводить до недостатнього вилучення флавоноїдів і до забруднення витяжки баластними речовинами. Концентрація спирту вище 70 \% не дозволяє вилучити флавоноїди у формі глікозидів. Флавоноїди вважаються стійкими хімічними ознаками виду. Тому їх ідентифікація та кількісне визначення має значення і для виявлення закономірностей їх синтезу залежно від сезону, віку рослини, для вивчення впливу екологічних факторів на накопичення флавоноїдів, а також для визначення оптимальних умов заготівлі сировини (Ломбоева, 2008; Шостак, 2014а; Шостак, 20146).

Згідно з літературними даними для визначення кількісного вмісту суми флавоноїдів найчастіше використовується метод диференціальної спектрофотометрії з реактивом алюмінію хлоридом (Ломбоева, 2008; Литвиненко, 2016; Blyznyuk et al., 2016.). Хоча у деяких публікаціях зазначається метод прямої спектрофотометрії з реактивом алюмінію хлоридом (Сорокина, 2013). Принцип спектрофотометричного методу з алюмінію хлоридом базується на комплексоутворенні алюмінію з С-4 кетогрупою і гідроксильними групами С-3 та С-5, а також іншими гідроксильними групами кілець A i/або В молекул флавоноїдів. Комплекси таких флавонів як хрізин, апігенін та лютеолін з алюмінію хлоридом мають максимум поглинання при наступних довжинах хвиль 395, 385 і 415 нм, відповідно, а комплекси таких флавонолів як рутин, кверцетин, кверцетрин, мірецитин в діапазоні 415 - 440 нм (Chan et al., 2002), рутин 412 нм (Чечета, 2011), 414 нм (Ломбоева, 2008). Власні дослідження показали, що спектр поглинання кверцетину з алюмінію хлоридом має максимум поглинання при довжині хвилі $425 \pm 2$ нм у діапазоні концентрацій кверцетину дигідрату 2,08 - 31,2 мг/л. Однак вищезгадані методи не дають можливості ідентифікувати які саме флавоноїди вміщуються у сировині, оскільки спектри різних комплексів флавоноїдів з алюмінію хлориду накладаються, оскільки їх максимуми поглинання знаходяться близько один до одного. Додавання алюмінію хлориду та використання як компенсаційного розчину досліджуваного зразку без алюмінію хлориду дає можливість визначати вміст флавоноїдів та усунути вплив інших забарвлених біологічно активних сполук, які поглинають світло (метод диференціальної спектрофотометрії) (Чечета, 2011; Blyznyuk et al., 2016). Вибір аналітичної хвилі, за якої проводиться кількісне визначення, встановлюється на основі максимуму поглинання рослинного продукту з алюмінію хлоридом. Вибір аналітичного маркера для кількісного визначення флавоноїдів здійснюється 3 урахуванням близькості спектрів поглинання комплексів маркерів з Al (III) і спектрів поглинання витяжок з алюмінію хлоридом та/або даних хроматографії (Чечета, 2011; Сорокина, 2013). Такий підхід, на наш погляд, дозволяє зменшити похибку визначення сумарного вмісту флавоноїдів при перерахунку на відповідний аналітичний маркер.

Згідно з літературними даними максимуми спектрів поглинання комплексів флавоноїдів з Al (III) в спектрах знаходяться в діапазоні від 406 до 430 нм, а саме при 406 нм для екстракту ліщини звичаайної (диференціальний спектр); при (410 2 нм) для плодів шипшини (диференціальний спектр); при 410 - 412 нм для екстрактів листя та пагонів верби тритичинкової (диференціальний спектр); при 413,5 нм для софори японської (прямий спектр); при 416,5 нм - для лушпиння цибулі (прямий спектр); при 414 нм для надземної частини ортілії однобокої (диференціальний спектр); при 418 нм для цмину піщаного (прямий спектр); при 430 нм - для прополісу (прямий спектр). Під терміном «диференціальний спектр» йдеться про спектр витяжки 3 алюмінію хлоридом з компенсаційним розчином, який вміщує всі компоненти досліджуваного розчину, за винятком алюмінію хлориду, а під терміном «прямий спектр» - спектр витяжки з алюмінію хлоридом з компенсаційним розчином - етанолом. Для перерахунку вмісту флавоноїдів у екстрактах верби тритичинкової, ліщини звичайної, плодів шипшини, софори японської та лушпиння цибулі як аналітичний маркер використовувався рутин, в прополісі - кверцетин. 
Уміст флавоноїдів подається найчастіше в перерахунку на кверцетин або рутин (Ломбоева, 2008; Чечета, 2011; Сорокина, 2013; Литвиненко, 2016; Blyznyuk et al., 2016). Для цмину піщаного кількісний вміст флавоноїдів різними фармакопеями перераховується або на рутин (не менше $2,5 \%$ ), або кверцетин (не менше $0.5 \%$ ) або халконовий глікозид ізосаліпурпозид (не менше 0,5\%) (Литвиненко, 2016).

Відповідно до власних експериментальних даних максимум поглинання екстрактів пилку ліщини звичайної в диференціальному спектрі знаходився в межах 405 - 410 нм, а екстрактів перги в межах 403 - 412 нм. Максимум поглинання екстрактів перги залежав від місяця і року збирання перги (Hudz et al., 2017).

За літературними даними для встановлення стійкого забарвлення випробуваного розчину і його стабільності проводяться дослідження протягом 1 години після приготування реакційної суміші. Для отримання стабільних результатів, оптимальним $\epsilon$ використання як комплексоутворюючого реагента 2 \% спиртового розчину алюмінію хлориду в співвідношенні з екстрактом: 1 : 1 . Максимальна оптична густина розчинів досягається через 30 хвилин після додавання реактиву (Чечета, 2011).

\section{Висновки}

Нами запропонований наступний підхід визначення сумарного вмісту флавоноїдів на основі літературних даних та експериментальних досліджень: Оптична густина реакційної суміші витяжки 31 мл 2 \% розчину алюмінію хлориду гексагідрату повинна знаходитися в межах від 0,1 до 1,0 при використанні 1 мл витяжки або її відповідного розведення. При значенні оптичної густини більшого ніж 1.0 необхідно зменшити об'єм витяжки або її відповідного розведення з компенсацією об'єму розчинником і введенням необхідних коефіцієнтів у формулу розрахунку сумарного вмісту флавоноїдів. Для кожного рослинного об'єкту необхідно встановити час стабільності комплексу флавоноїдів з алюмінію хлоридом. У процесі проведення власних досліджень цей комплекс був стійкий протягом 65 - 95 хв. Дослідження сумарного вмісту флавоноїдів доцільно проводити 3 ідентифікацією домінуючої групи флавоноїдів шляхом визначення максимуму поглинання в диференціальному спектрі. Максимум поглинання $\epsilon$ необхідний і для вибору аналітичного маркеру з ідентичним або близьким максимумом поглинання його комплексу з алюмінію хлоридом в ідентичному розчиннику. Спектрометричні дослідження доцільно доповнити хроматографічними для підтвердження правильності вибору аналітичного маркеру для перерахунку суми флавоноїдів.

\section{Acknowledgments}

The publication was prepared with the active participation of researchers involved in the International network AgroBioNet of the Institutions and researchers for realization of research, education and development program «Agrobiodiversity for improving nutrition, health and life quality» and within the project ITMS 25110320 104. Co-author Nataliia Hudz thanks to the International Visegrad Fund for scholarship and research internships, during which were got the results and knowledge presented in this paper.

\section{Література}

Blyznyuk, N., Prokopenko, Yu., Gergiyants, V. 2016. Development of methods for determination of phenolic acids and flavonoids in capsules containing Corylus avellana L. dry extract. Journal «Science Rise», no. 2/4 (19), p. 18-22.

Chang, Ch.-Ch., Yang, M.-H., Wen, H.-M., Chern, J.-Ch. 2002. Estimation of Total Flavonoid Content in Propolis by Two Complementary Colorimetric Methods. Journal of Food and Drug Analysis, vol. 10, no. 3, p. 178-182. 
Fatrcová-Šramková, K., Nôžková, J., Márriássyová, M., Kačániová, M. 2015. Biologically active antimicrobial and antioxidant substances in the Helianthus annuus L. bee pollen. Journal of Environmental Science and Health, vol. 51, no. 3, p. 176-181.

Hudz, N., Brindza, J., Grygorieva, O., Schubertová, Z., Filipska, A., Ivanišová, E. 2017. Phytochemical studies of bee bread extracts. Збірник праць Х міжнародної міждисциплінарної науково-практичної конферениії до 25-річчя заснування НДІ фітотерапії ДВНЗ «Ужгородський начіональний університет»: Сучасні аспекти збереження здоров'я людини, Ужгород, с. 80-83.

Ivanišová, E., Kačániová, M., Frančáková, H., Petrová, J., Hutková, J., Brovarskyi, V., Velychko, S., Adamchuk, L., Schubertová, Z., Musilová. J. 2015. Bee bread - perspective source of bioactive compounds for future. Potravinarstvo Slovak Journal of Food Sciences, vol. 9, no. 1, p. 592-598. https://doi.org/10.5219/558

Шостак, Т.А., Калинюк, Т.Г., Гудзь, Н.І. 2014а. Застосування рослинних субстанцій в якості активних фармацевтичних інгредієнтів. Фітотерапія, № 3, с. 63-65.

Шостак, Т.А., Калинюк, Т.Г., Гудзь, Н.І. 20146. Особливості фармацевтичної розробки рослинних препаратів (огляд літератури). Фітотерапія, № 4, с. 77-82.

Литвиненко, В.И., Попова, Т.П., Попова, Н.В., Георгиевский, В.П. 2016. Квопросу об изосалилпурпозидестандарте в контроле сырья и фитопрепаратов из бесмертника песчаного. Фармаком, № 3 , c. 23-27.

Ломбоева, С.С., Танхаева, Л.М., Оленников, Д.Н. 2008. Методика количественного определения суммарного содержания флавоноидов в надземной части ортилии однобокой (Orthilia secunda (L.) House). Химия растительного сырья, № 2, с. 65-66.

Санникова, Е.Г., Попова, О.И., Фролова, О.О., Айрапетова, А.Ю. 2016. Изучение флавоноидов ивы трехтычинковой (Salix triandra L.), произростающей на Севернем Кавказе. Фармачия и фармакология, с. 56-67.

Сорокина, О.Н., Сумина, Е.Г., Петракова, А.В., Барышева, С.В. 2013. Спектрофотометрическое определение суммарного содержания флавоноидов в лекарственных препаратах растительного происхождения. Известия Саратовского университета. Новая серия. Сер. Химия. Биология. Экология, т. 13, вып. 3, с. 8-11.

Чечета О. В., Сафонова Е.Ф., Сливкин А. И., Снопов С. В. 2011. Определение флавоноидов в плодах шиповника (Rosa sp.). Вестник ВГУ, Серия: Химия. Биология. Фармация, № 11, с. 205-209. 